\title{
THE IMPLEMENTATION OF IMAGINATIVE TECHNIQUE IN IMPROVING STUDENTS' WRITING ABILITY ON DESCRIPTIVE TEXT AT THE SECOND GRADE OF MTs. MUHAMMADIYAH SIDOMULYO
}

\author{
Agus Salim Lamusu \\ Economic and Social Sciences Department \\ Muhammadiyah University of Gorontalio \\ agussalimlamusu@gmail.com
}

\begin{abstract}
The aims of the research was to get the data how Imaginative Technique Method can improve students' writing ability on descriptive text at second grade MTs. Muhammadiyah Sidomulyo with target achieved $75 \%$ from number of students at second grade average 70 . The research is class room research (CAR). Subject of this research is students' second grade. The instruments of this research are test and observation sheet. The technique of analysis got by formula total students' completeness divided total students' multiplied one hundred percent. The result of this research point out Imaginative Technique method can improve students' writing ability on descriptive text at second grade. This research carried out in two cycles where each cycle consists from two meeting. Cycle I grade average of students get 69.2 and cycle II grade average of student get 75.4 .
\end{abstract}

Keywords: Writing Ability, Descriptive Text, Imaginative Technique.

\section{INTRODUCTION}

Learning English involves four basic skills: writing, speaking, reading and listening. Writing and speaking are productive skills while reading and listening are receptive skills. As productive skills, writing and speaking are cognitive activity, how to make written and oral language. In writing, mastery grammar is one of important aspects: therefore students' grammatical ability is very influential towards student' writing skill. Hamp Lyons and Heasly in Nunan state writing is clearly a complex process and competent writing is frequently accepted as being the last language skill to be acquired (David Nunan: 1991:91).

According to Hedge, it can be said that writing is a complex process that moves through a number of stages. On the other hand, speech is a spontaneous

\section{British, Jurnal Bahasa dan Sastra Inggris}


action which requires very little preparation. We open our mouths and out flow the words (Tricia Hedge: 1990:7).

Among the four language skills taught in schools, writing is the most difficult skill to learn. It needs specialized skills that include the ability to express the writer's opinions or thoughts clearly and efficiently. These abilities can be achieved only if a learner masters some techniques of writing such as how to obtain ideas about what s/he will write on, how to express them in a sequence of sentences, how to organize them chronologically and coherently, and how to review and then to revise the composition until the writing is well-built. In this research the researcher took the descriptive text as the skill of writing will be given to the students. Descriptive Text is a kind of text with a purpose to give information. The context of this kind of text is the description of particular thing, animal, person, or others, for instance: our pets or a person we know well. (M Mursyid: 4).

Another idea about writing is expressed by Raimes. Learning to write is not "natural "extension of learning to speak a language (Ann Raimes: 1983:4). It means that we do not need systematic instruction when we learn to speak our first language at home, while most of us had to be taught in school how to write that same language by using systematic instruction.

Besides the reason writing is endless yet. Normally we write for the following reason, to communicate ours ideas, though and feelings. Therefore, in the classroom the teacher must create situation that can encourage real communication, many activities can be designed to make major's element lively. Teacher has innovative soul and full creation should think manner that can be used in writing, but there are some teacher ignore what faced by the student so that teacher swimmingly give task writing to student without giving a technique that make them easy to writing something.

The statement from English Teacher at MTs. Muhammadiyah sidomulyo that the average value from all students still not yet maximal. Pursuant to our perception result, in course of English study at MTs. Muhammadiyah sidomulyo still use the method which center on teacher (teacher oriented). Students inactive 
in course of study, so that happened the student isn't understand with the lesson, and all students feel difficulty reply the questions that given by teacher about the lesson especially the Writing skill especially about descriptive text. Descriptive Text is a kind of text with a purpose to give information. The context of this kind of text is the description of particular thing, animal, person, or others, for instance: our pets or a person we know well, meanwhile all teachers confess that they have tried to teach in the form discourse and or other monologue technique.

In this case, English subject becoming one of subject tested in National Test, than it so importance to be optimal zed and maximized in course of study to reach the reached value standard according to National standard value.

According to the several things, the researcher suggests method, namely "Imaginative Technique". Imaginative technique developed by Lyman Frang and colleague at the University of Maryland in accordance quoted Arends, states that the imagination technique is an effective way to create an atmosphere variation pattern class discussion. Assuming that all recitation or discussion requires a setting to control the class as a whole, and the procedures used in the engineering imagination can give students more time to think, to respond and help each other.

According Musbikin explains, "In epistemology, imagination placed on the second position after the senses as the knowledge base. That's because the imagination cannot stand alone. Imagination can work after the senses perceive certain objects. The object is then stored in the human mind in the form of immaterial. Therefore, only the imagination can describe something in essay though sensory materials have been disconnected from reality.

Developing imagination in students' thinking can improve the flexibility, creativity and energy of thought. Then the goal is to create imaginative education students who know, who are able to think flexibly, creatively and with the energy of the science that they have about the world and experience, where all students expected can more active and participate in course of study and expected able to improve and repair the previous method.

As according to description above, researcher will perform a research at MTs. Muhammadiyah sidomulyo with the title "The Implementation of

\section{British, Jurnal Bahasa dan Sastra Inggris}


Imaginative Technique in Improving Students' Writing Ability on Descriptive Text at The Second Grade of Mts. Muhammadiyah Sidomulyo". There are three successfull indicators of this research. The first, teachers' successfull indicator during teaching learning proccess is categorized into good. Second, observation sheet of students' categorized into good. Third, 75\% students from 20 students got score 70 in writing descriptive text.

\section{RESEARCH METHOD}

This research was classroom action research. Action research is about both "action" and "research" and the links between the two. It is quite possible to take action without research or to do research without taking action, but the unique combination of the two is what distinguishes action research from other forms of enquiry. It is, of course, not restricted to an educational context, though that is the focus of this Guide (Walton Hall: 2005:4).

The Classroom Action Research (CAR) procedure is used in this research is Walton Hall design. It consists of two cycles in which each cycle contains four phases; planning, acting, observing, and reflecting. Moreover, in this study the writer will conduct this classroom action research into two cycles. It means that a classroom action research should be conducted at least in two cycles. If the results are less satisfactory, researchers can perform the cycle once again in order to achieve the criteria that have been determined.

The phases of classroom action research that modified by witter (adapted from Walton Hall Action Research Design) (Walton Hall:2005:5).

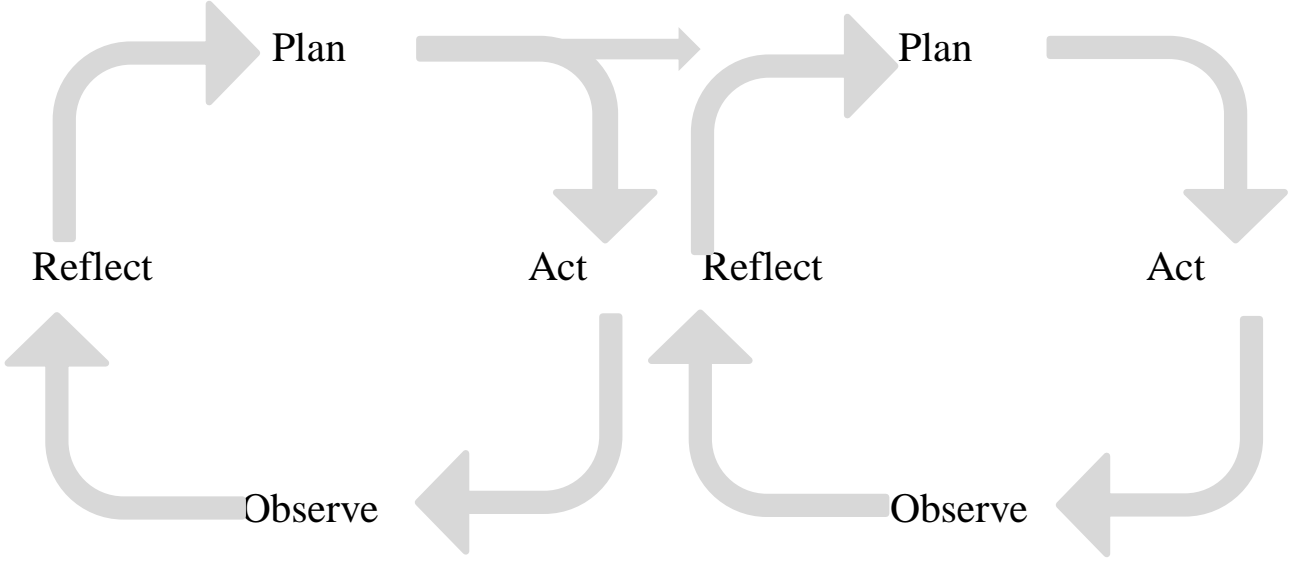


The Classroom Action Research using Wilton Hall design consists of four phases with in one cycle. Those are planning, acting, observing, and reflecting. After accomplishing the first cycle, it will be prochapterly found a new problem or the previous unfinished problems yet. Therefore, it is necessary to continue to the second cycle in line with the same concept of the first cycle.

Before conducting the research, the researcher prepared some instruments. The instruments in this study were observation sheet, and test (fre-test and posttest). The observation sheet for check the English teacher's activity and students' activity in English learning process in the class. The test used in this study is pretest and post-test. The pre-test is done before implementing Imaginative technique. It is to measure students' ability in writing descriptive text at first. Meanwhile, the post-test is implemented after using Imaginative Technique. The test is held on every second action of each cycle.

Acording to Brown, there are five aspects, which are used as consideration in scoring. They are organization, content, grammar, mechanic and vocabulary. The researcher gives score for each elements of writing and explains the score for each elements of writing (H. Douglas Brown: 2004:244-246).

Table of component of writing

\begin{tabular}{cccc}
\hline No & Categories & Lowest score & Highest score \\
\hline $\mathbf{1 .}$ & Content & 13 & 30 \\
\hline $\mathbf{2 .}$ & Organization & 7 & 20 \\
\hline $\mathbf{3 .}$ & Vocabulary & 7 & 20 \\
\hline $\mathbf{4 .}$ & Language use & 5 & 25 \\
\hline $\mathbf{5 .}$ & Mechanic & 2 & 5 \\
\hline
\end{tabular}

The researcher used the criteria of assessment, that is, since the content of students writing covered the generic structures, they are identification and description. In generic structure of description consists of parts, qualities, and 
characteristics. In assessing the result of students' writing organization of descriptive text, the steps of analysis are;

1. The data analyzed of teacher's and Student's activities

The assessment criteria of teacher's activities consists of five, namely Very good, Good, enough, poor, and very poor. The data of teacher's activities will be analyzed by using the following formula :

Percentage $=\frac{n m}{N} \times 100 \%$

Notes ;

$\mathrm{Nm}$; Number of checking aspects

$\mathrm{N}$ : total of assessment aspects

Predicate of teacher's and Student's activity is :

$\begin{aligned} 85-100 & =\text { Verv Good } \\ 70-84 & =\text { Good } \\ 55-69 & =\text { Enough } \\ 39-54 & =\text { Poor } \\ 0-38 & =\text { Very poor }\end{aligned}$

2. The data analyzed result of writing descriptive text

The data of writing assessment will be analyzed by using the following formula :

$$
\text { Percentage }=\frac{n m}{N} X 100 \%
$$

Notes ;

$\mathrm{Nm}$; Number of checking aspects

$\mathrm{N}$ : total of assessment aspects

\section{RESEARCH FINDING AND DISCUSSION}

This research is conducted in two cycles, but before conducting the action research in two cycles, the researcher conducted the fre test.

Based on the result of the fre test most of the students had difficulties in organizing the words grammatically. It could be seen from their writing result. 
It found many organized words ungrammatically in the students' writing. Beside that they consumed the time only thought about the words that would be written.

The researcher gave a test that students were asked to write a descriptive text with the theme describing place especially the place are visited by them. The test was followed by 20 students as the participants of the study and they gave 30 minutes to do it. The purpose of the test was to measure students' achievement before given an action.

After giving the test, the researcher examined the answer sheet and found the results. that students' writing ability is still very low. Proved with average score that get by students on the fre-test are 57,4. while for completeness minimum value specified is 70 . It indicates that the success target not achieved, then the classroom action research is necessary to be done.

\section{The Result of Cycle I}

Cycle I carried out in two meetings, during the teaching and learning process, the researcher was collaborated with the English teacher in running the action. The collaborator observes the researcher as the teacher during the process by filling the observation sheet has been prepared.

This cycle focused on how to write descriptive text by using imaginative technique. By using imaginative technique is expected the students to be more active and can improve students' writing ability on descriptive text.

The Implementation of the learning writing though imaginative technique on cycle I with the subject describe a people (Jokowi). This method is used to motivate students to learn writing and excite learning English. However, the method was used new and some students still not have become accustomed to learning by use imaginative technique. Then, the students seen less active during teaching learning process. So, can be classified into the category of poor.

The statement above can be seen in the average score of the analysis of learning by using imaginative technique on cycle 1 that result of final test measures the cycle 1, obtained an average grade 69,2. The highest score was 77 and the lowest score was 60. Learning achievement has not been achieved according to the criteria of success defined action. Acquisition value of the cycle I

\section{British, Jurnal Bahasa dan Sastra Inggris}


increased slightly from the test results before the action. Incresing success of students learning guite a lot that is from 1 student become 9 students. Despite an increase in cycle 1, but still not achieved the specified learning exhaustiveness that is at least $75 \%$ or a minimum 15 students who complete.

\section{The Result of Cycle II}

Cycle II carried out in two meetings. Carrying out of learning in cycle II same with in cycle I that is about writing descriptive text but only carrying out on cycle II more gives stressing about things that yet know which carrying out gift of material on cycle II same with in cycle I. Implementation of the learning though imaginative technique on the cycle II with material of learning is describing animal (favorite animal). The cycles II is only performed repairs on the basis of reflection on the cycle I. Because in the cycle I the standard target have not achieved. So it must be improved on cycle II.

On the cycle II emphasizes how the students more motivated, active and more provoked as well as have mastery writing ability, so they can enhance their writing skill to write in English well . Because the cycle I most students are still shy to ask. And in the cycle II obtained maximum result is success. Becouse it exceeds the target achievement $75 \%$. It was $80 \%$.

The statement above can be seen in the average score of the analysis of learning by using imaginative technique methode on the cycle II. The last result of final test earned an average grade 75,4. The highest score was 86 and the lowest score 66. Learning achievement has achieved according to the criteria of success defined action. Grade of cycle II increased slightly from the test results before the action and increased when compared with the first action. Students who completed before the action was 1 student or $5 \%$, and after cycle 1 was 9 students or $45 \%$, it means in the cycle II increases. It was 16 students who complete or $80 \%$. It means that increasing $35 \%$ of cycle I. From cycle II can be knowing that the learning success of students have achieved learning exhaustiveness or the target has been set before action.

Based on description the result of research and discussion had explained above, the method succeeds to improving students' writing as with successful 
indicator that hoped. Therefore, so hypothesis of classroom action research had formulated was "the implementation of imaginative technique in improving students' writing ability on descriptive text $75 \%$ at the VII grade of MTs. Muhammadiyah Sidomulyo can be accepted.

From pretest, cycle I and cycle II, the students' concept and test score by writing descriptive text has increased. Can be seen in the following table:

Table I

\begin{tabular}{|c|c|c|c|c|c|}
\hline \multicolumn{6}{|c|}{$\begin{array}{c}\text { Students' Achievement Before Action And After Action } \\
\text { At Cycle I and II }\end{array}$} \\
\hline \multirow{2}{*}{ Cycle } & \multirow{2}{*}{ Mean } & \multirow{2}{*}{$\begin{array}{l}\text { Students } \\
\text { Complete }\end{array}$} & \multirow{2}{*}{$\begin{array}{c}\text { Students } \\
\text { not Complete }\end{array}$} & Percentage & \multirow[b]{2}{*}{ Note } \\
\hline & & & & $(\%)$ & \\
\hline fre-Test & 57,4 & 1 & 19 & 5 & \\
\hline Cycle I & 69,2 & 9 & 11 & 45 & \\
\hline Cycle II & 75,4 & 16 & 4 & 80 & \\
\hline
\end{tabular}

The following presented an increasing students' writing ability in learning by imaginative technique methode. By increasing of average score obtained by students during cycleI to cycle II compared before action can be seen on the following diagram picture below:

\section{DIAGRAM}

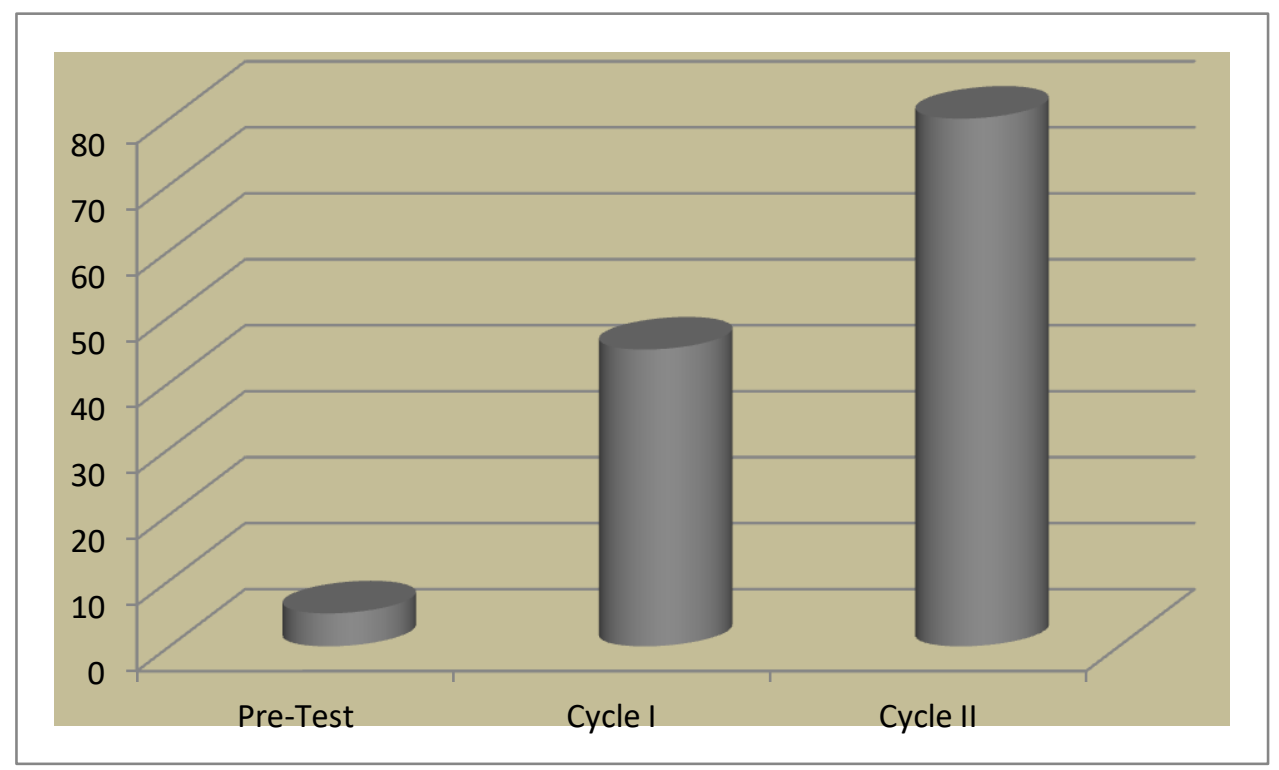

Picture I : Bar Chart Student Achievement During Cycle I-II

\section{British, Jurnal Bahasa dan Sastra Inggris}


According to the table and diagram above, it can be explained that the learning outcomes of students before action for two cycles increased. This increase can be achieved because the teacher did well convey the subject matter of English by using imaginative technique method to write in English.

\section{CONCLUSION AND SUGGESTION}

The using of imaginative technique as a media to improve students' ability writing descriptive text was an alternative way. Imaginative technique was the media that can make students more interest with the material of writing descriptive text. By using descriptive text, teacher can stimulate the students to write in descriptive form. The students more enjoyed when they want to write their opinion. Imaginative technique is an excellent methode, the students have to think about a people, and animal and arrange it in the simple paragraph of descriptive text. The using imaginative technique was interest and motivated students to learning writing easly.

Based the result of the research that had been done in two cycles ( cycle 1 and cyle 2), it can be taken the conclusions that there is an improvement. The student's ability in writing descriptive text improve after being taugh by using imaginative technique. The implementation of imaginative technique as a methode to improve student's ability in writing descriptive text was very effective. It was supported by the significance result of students score in the fre test $(57,4)$ cycle $1(69,2)$, and cycle $2(75,4)$

The using of imaginative technique in teaching and learning english was interesting for the students ; it could be seen in the result observation and the result test. The researcher uses imaginative technique as methode of learning aid becouse it can motivated students to learned english writing more fun and easly. However,there some problem in using imaginative techniqueto improve students writing skill, for the example some of students ware confused becouse some of them is never wrote paragraph of descriptive text. So the english teachers had to give some explanation about descriptive text. 


\section{REFERENCES}

Hedge, Tricia. (1990) Writing. Oxford: Oxford University Press

Raimes, Ann. (1983) Technique in Teaching Writing, New York: Oxford University Press

Hall, Walton, and Keynes, Milton. (2001) Action Research a Guide for Associate LecturersWaltonal, the open university

Bown, H. Douglas. (2001) Teaching by Principles: An Interactive Approach to Language Pedagogy, New York: Addison Wesley Longman

M Mursyid PW, LEARNING DESCRIPTIVE TE

British, Jurnal Bahasa dan Sastra Inggris 